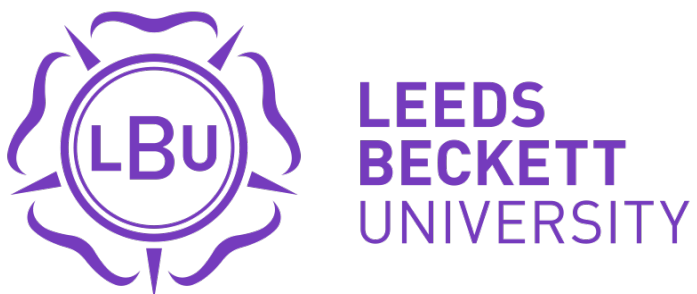

Citation:

Tomassini, L and Font, $X$ and Thomas, $R$ (2019) The case for linguistic narrative analysis, illustrated studying small firms in tourism. Tourism Geographies. ISSN 1461-6688 DOI: https://doi.org/10.1080/14616688.2019.1619824

Link to Leeds Beckett Repository record:

https://eprints.leedsbeckett.ac.uk/id/eprint/5960/

Document Version:

Article (Accepted Version)

The aim of the Leeds Beckett Repository is to provide open access to our research, as required by funder policies and permitted by publishers and copyright law.

The Leeds Beckett repository holds a wide range of publications, each of which has been checked for copyright and the relevant embargo period has been applied by the Research Services team.

We operate on a standard take-down policy. If you are the author or publisher of an output and you would like it removed from the repository, please contact us and we will investigate on a case-by-case basis.

Each thesis in the repository has been cleared where necessary by the author for third party copyright. If you would like a thesis to be removed from the repository or believe there is an issue with copyright, please contact us on openaccess@leedsbeckett.ac.uk and we will investigate on a case-by-case basis. 


\title{
The case for linguistic narrative analysis, illustrated studying small firms in tourism
}

Tomassini, L.

School of Events, Tourism and Hospitality Management, Leeds Beckett University, UK

Font, $\mathrm{X}$.

School of Hospitality and Tourism Management, University of Surrey, UK

Thomas, R.

School of Events, Tourism and Hospitality Management, Leeds Beckett University, UK

\begin{abstract}
We advocate the adoption of more expansive and creative methodological approaches the study of tourism. More specifically, we argue that by examining how individuals narrate their experiences and social practices, researchers can gain an insight into the meanings actors attach to their actions. Considered from this perspective, narratives become performative; they prompt actors to take actions that (they feel) actualise the story they are seeking to tell. To illustrate its value, we use linguistic narrative analysis to explore how the ownermanagers of small values-based tourism firms narrate the operation of their business. A dataset of first person accounts made of both narratives in storified form featuring a chronological order with beginning, middle, and end, and narratives without a storified form largely recounting opinions, feelings, and points of view, are interpreted to offer new perspectives on the behaviours of small firms in tourism. We argue that narrative approaches should complement methods used routinely by tourism scholars to examine this constituency of actors (and others).
\end{abstract}

Keywords: narrative approach, stories, linguistic analysis, small tourism firms, identity, social practice, values, sustainability, ethics

\section{Introduction}

Narrative research methods are under-utilised in tourism studies despite their acknowledged strengths and growing application in other fields of enquiry (Riessman, 1993, Smith \& Sparkes, 2008). In this paper we seek to show how a narrative approach can generate new knowledge by revealing the meanings actors ascribe to their actions. We discuss research 
undertaken with owner-managers of small firms in tourism that define themselves in terms of their ethics to illustrate our argument. Following others, 'smallness' refers to the personalised nature of organisational management, which is reflected by the employment of a maximum of fifty people (Walmsley, 2019). We show how narrative enquiry enhances knowledge generated about such firms using more 'standard' or 'conventional' methodologies and methods.

Narrative research lends itself to a dynamic, holistic, qualitative and interpretive understanding of complex systems (Tsoukas \& Hatch, 2001). Its strength lies in allowing multiple connections across time and linking disconnected elements as related parts of a whole. The narrative approach is not a search for truth but a search for meaning (Rhodes \& Brown, 2005). Narrative research embraces a postmodern perspective that challenges singular, and often essentialist, theories in favour of an interpretive approach that acknowledges the presence of fragmentation and tensions in the processes of sense making (Buchanan, 2013). Individuals and groups construct narratives in order to organise their experiences and 'map their reality' (Wilkins \& Thompson, 1991). Its starting point is an acceptance that all social actors position themselves - and others - through stories about themselves and others (Davies \& Harré, 1990).

Narratives are a mode of association enabling an alternative way of knowing. They are a distinct form of discourse that focuses on the biographical, social, cultural and historical situations that have conditioned life experiences (Denzin \& Lincoln, 2005). Narrative enquiry, therefore, revolves around life experiences as narrated by those who live them. They are a way in which individuals create coherence and meaning, reflecting their understanding of events and behaviours over time (Chase, 2005; Denzin \& Lincoln, 2005). While conceptually appealing, the methodological challenges of data capture are significant. The section that follows discusses one way of collecting narrative data (for a discussion of others see Andrews et al., 2013; Reissner and Pagan, 2013) and an approach to interpretation in tourism studies.

\section{Narrative data collection and transcription}

Informal and unstructured interviews allow for close observation of a few individuals so as to scrutinise their narratives carefully, and thus interpret the meaning they attach to them (Riessman, 1990; Bredvold \& Skålén, 2016). The researcher (in this case the first author) is the listener and the founder/owner-manager the storyteller. For each participant, the researcher organised an interview via Voice over Internet Protocol (VoIP) - Skype audio call - since participants were located in different parts of Italy. Each interview lasted between 45 and 80 minutes. Through questions like "Would you tell me in your own words the story of 
your firm? How have things changed over the time? How does it work now?", the researcher elicits the conversation with a set of open and flexible questions as guidelines for the conversation (Riessman, 1993). The data collection resulted in a set of first person accounts in Italian - the mother tongue of both researcher and participants - which where translated into English only after being carefully transcribed and analysed. After the first rough transcription, the researcher proceeds with a careful reiterated reading of the text together with further listening to the audio file.

This second phase of the transcription process focuses on working on a more detailed rendering of the conversation, removing all the researcher's questions and interactions. This also means transcribing the extra linguistic features of the conversation in order to render the nuances and the complexity of a spoken language as closely as possible in the written text (Gee, 1991; Riessman, 1993). Making sense through narratives requires the analysis and interpretation of multiple potential meanings, tensions and contradictions, including examining the linguistic and extra-linguistic features of first person accounts. Hence, it requires re-transcribing the interviews, adding utterances, verbal emphasis, vocalisations, short pauses, long pauses, word repetitions, dysfluencies, deep breathes, laughs, sighs, and sniffs. The additional non-narrative linguistic details help to initiate the narrative analysis of each interview, since the analysis cannot be easily separated from the transcription (Riessman, 1993). This allows the identification of different parts of the text and potential boundaries among them.

The next step is to start 'unpacking' the narratives by identifying the beginnings and endings of the different narrative segments. The transcript of each participant's interview allows the identification of segments contributing to chronological ordering, as well as those mainly concerned with personal opinions and comments. This allows the differentiation of stories stretches of narratives with a storified form and a plot with beginning, middle, and end - and stretches of narrative largely recounting opinions, feelings, and points of view without a temporal order - (Cunliffe et al., 2004; Boje \& Durant, 2013). With the exception of few segments with a chronological order and storified form, the data result in a set of first person accounts organised thematically and episodically.

\section{Narrative data analysis}

Narrative analysis is an umbrella phrase that describes several possible methods designed to frame the analysis of stories and narratives (Riessman, 1993; Smith \& Sparkes, 2008). All commentators accept that narratives do not speak for themselves and, therefore, require interpretation when used as data in social research (Riessman, 1993; Riessman \& Quinney, 2005; Smith, 2000). To illustrate the potential value of narrative research, we adopt Gee's 
(1986; 1991) linguistic approach to studying narratives episodically; sectioning them into idea units, stanzas and strophes on the basis of how the narratives are spoken. Hence, in this study we operate as a bricoleur, scrutinising, sectioning, linking, and interpreting a complex set of data through by building up holistic view.

\section{A linguistic approach}

In the linguistic approach to narrative, text can be 'unpacked' according to its different levels of structure and meaning (Gee, 1991; Riessman, 1993). The researcher organises the text, identifying pitch glides - movements in the tone of the speaker - and transfer them into the written text by marking the point of each variation of tone with a slash. Each pitch glide marks what Gee defines as an 'idea unit'; a movement in the tone of voice identifying a change of focus in the speaker's discourse. Each pitch glide corresponds to a different focus and to a new piece of information that forms a different idea unit. The researcher organises the text in numbered lines, each one consisting of one or more idea units separated by slashes (Gee, 1991). This means that - in general - every line features a central idea, articulated syntactically and intonationally.

Once the text is organised in terms of idea units and lines, the researcher groups lines into larger units, defined as stanzas (Gee, 1986; 1989; 1991; Riessman, 1993). A stanza consists of a group of lines about a single topic; it captures a single scene, a notional image on a specific person, event, claim, or piece of information. Hence, stanzas are the basic elements of long pieces of discursive narrative such as descriptions, arguments and personal opinions. Following the example of Gee (1991), stanzas on the same or similar topics are linked to make a larger unit called a strophe. Strophes, in turn, fall into still larger units called parts. It is these that assemble the narrative as a whole, representing the different chapters of the story.

This first level of analysis acts as a foundation on which the other levels of analysis of structure and meaning are built. Once the text is structured into idea units-lines-stanzasstrophes-parts, the researcher moves to a second level of analysis separating the main line of the plot from the remaining material. The researcher identifies the main line through the use of present tense verbs or historical present verbs; non-subordinate and non-embedded clauses.

This level of analysis is the basis for the third level, which focuses on the psychological subjects of main sentences. The psychological subject does not always coincide with the grammatical one; the researcher needs to examine them because "such subjects are 'psychological launching off' points in a stanza; they represent points of view from which the 
material of a stanza is viewed; they represent what the narrator is 'empathising' with" (Gee, 1991, p.23). The researcher needs to interpret their variety, their repetition, and the switch of viewpoints throughout the text.

The fourth level of structure and meaning examines the focusing system. Following Gee (1991) the researcher can identify the focused material across the stanzas of the whole narrative. The focused material consists of key images or themes recounted by the participants and contributing to establishing an overall interpretation of the whole narrative. The researcher can highlight the focused material - words, verbs, adjectives and rhetorical figures - of each stanza with the idea of performing a thematic interpretation supported by the previous levels of analysis. In this level, the role of the researcher as interpreter is crucial to connect and give sense to the whole structure of the text in terms of key images and themes. The identification of the focusing system and its thematic interpretation is an interpretative reading where the researcher is aware that there could be a number of other possible thematic readings and interpretations but also a number of impossible ones, due to the previous levels of structure (Gee, 1991). Focused material coming from different lines needs to be separated, in this case by a cross hatch ("\#"), and material coming from different idea units but in the same lines, can be separated by a comma. An example can be seen in Table 1.

< Insert Table 1 about here - Caption: Table 1 - Sample of a linguistic approach to data analysis - Participant 1 - Source: 'Tables' file >

\section{The narratives of small tourism firms}

A research project that examined the decision-making of socially and environmentally responsible tour operators is now used to exemplify the use of narrative research. The seven participating owner-managers studied were members of the Italian Association for Responsible Tourism (AITR). The association was established in the late 1980s as a nonprofit consortium and now consists of ninety-two members. Making an explicit ethical commitment to addressing global inequalities is one of the conditions of membership. These firms state - in their websites, brochures or leaflets - that their products contribute to ethical goals such as poverty reduction, local development, environmental conservation and cultural heritage preservation. Examples of the strophes and stanzas used are shown as part of a process of identifying three narrative types: i) the intellectual and educational, ii) the professional and entrepreneurial, and iii) the empathic 'free speech'. As these are being used to illustrate the value of the approach rather than to report the findings of the study, we limit the discussion of the key characteristics of each narrative type. As is often the case, there is a degree of overlap between the three (Riessman, 1993; Bredvold \& Skålèn, 2016). 
The research findings reveal how in this narrative type, participants understand themselves and their firms as subjects critically reflecting on tourism, contemporary society and development. Participants describe the shift from consumerism to citizenship by characterising themselves neither as managers nor as entrepreneurs but rather as individuals and citizens concerned with global challenges (Elkington, 1998; Klein, 2000). This resonates with the articulation of a firm that - at first - was just an idea and an indistinct amalgam of Fair Trade movement and ethical consumerism theorisations (Moore, 2004; Nicholls \& Opal, 2005). Participants understand the firm's identity as a private subject called to contribute to sustainable development and to educate people and travellers towards an authentic and responsible relationship with other cultures.

Participants' identity construction might be understood in in the context of a postmodern perspective or, perhaps, Bauman's (2000) liquid modernity; society is individualised and characterised by uncertainty. Participants understand their individuality and self-affirmation in opposition to a global and indistinct 'alterity'. Firms are recounted as subjects imbued with a sense of the value of artisan production and consumption that emphasises time, human relationships, cultural exchanges and local development.

Participant 1 (Table 2), for example, presents Firm 1 not as a tour operator but as a multifaceted association that includes Fair Trade, responsible tourism and cultural activities (lines 5 - 6). It is an idea about other worlds and their questions and themes (line 7). 'Stuff' means an indistinct amalgam. The word idea and its use play a key role, since Firm 1 originates from the idea of the 'yours truly' narrator (line 2). The idea in relation to Firm 1 is: 'stuff from other worlds', and themes and questions from a different world (line 7). The idea was to create a bridge connecting different cultures (line 10). Strophe 1 ends with the statement that dealing with responsible tourism is 'quite another idea'. For Firm 1, this means a critical discussion of tourism. In Stanza 02, the narrator makes clear that Firm 1 is, and always has been, a non-profit association (lines $04-06$ ).

< Insert Table 2 about here - Caption: Table 2 - Participant 1 - Source: 'Tables' file> From its beginning, Firm 1's scope was ambitiously wide; Fair Trade, responsible tourism, cultural activities, and a critical debate about tourism. The choice of the firm's name is meaningful as it implies an indistinct amalgamation of things that are, nevertheless, impossible to divide (line 06). A bridge connecting different cultures and different worlds is a key image and a powerful metaphor (line 10), as travelling is a way of escaping 
commercialism through the use of meaningful choices (line 11). Critics in the debate surrounding tourism are a constant feature of the entire narrative and also link Strophe 1 with Strophe 2. The 'quite another idea' of responsible tourism (line 17) is immediately recalled at the beginning of Strophe 2 (line 18) through the use of the pronoun "this" to explain the origin of the Italian Association for Responsible Tourism.

Participant 2 (Table 3) contextualises Firm 2's vision within a larger perspective. The narrator presents the 'imprinting' that they received from the Fair Trade movement. She recalls being 'outsiders' in the tourism sector. The subject is mainly 'we', referring to the work team and the original founders. The first person singular appears three times; when describing their first encounter with the Director of the Italian Association for Responsible Tourism, when stressing the narrator's role in the Association, and when giving an example of their transparent and sincere relationship with travellers. Stanza 13 narrates the imprinting of Fair Trade values on the firm's vision for tourism (lines 86 - 87). The word 'imprinting' recalls the study of ethology, the first knowledge gained in life. It is a meaningful choice of word to explain how Fair Trade has inspired their vision of tourism. It was originally an ethical selling point (line 88) for them, informed by the values of the Fair Trade movement. They commercialised Fair Trade products and other goods created by cooperatives and social enterprises (lines 92 - 93).

< Insert Table 3 about here - Caption: Table 3 - Participant 2 - Source: 'Tables' file>

The narratives from these two participants have some similarities with those of Participant 7 (Table 4). Strophe 13 details the reasoning behind participant 7's decisions by explaining his firm's vision: 'our work, which is very artisanal, really homemade' (line 148). The participant here links the firm's artisanal dimension with its capacity to provide unique products. He stresses that a 'unique piece' is the product of special, artisanal, and traditional knowledge. Even its imperfections make it extraordinary. Words such as 'unique-piece' (lines 152 and 153), 'artisanal' (lines 148, 150, 152 and 157), 'flaw' (lines 152 and 155), and 'virtue' (lines 155 and 156) are recurrent. This concept is expanded upon in Strophe 14, which explains why imperfections make artisanal products unique and valuable. The narrator stresses the importance of not becoming 'just a part of a big production chain' (lines 158). 'I wanted our strong and artisanal impact to stay, a very personalised relationship, also with our customers' (line 160); 'I still struggle to call them like this' (line 161), 'I call them participants' (line 162), 'I like it more' (line 163). 
< Insert Table 4 about here - Caption: Table 4 - Participant 7 - Source: 'Tables' file>

The professional and entrepreneurial narrative type

Some participants' narratives reflect an identity largely constructed in terms of entrepreneurship, efficiency and professionalism. First of all, these participants understand their entrepreneurial identity not only as the result of a long and peculiar path, but also as an innovative approach to the tourism and development agenda that goes beyond the constraints of profit / non-profit attitudes. The entrepreneurship model of innovation and disruption helps to locate participants' understanding and identity construction. Their selfintroductions largely revolve around being 'wild spirits', striving to do new things, or things that have already been done but in a new way (Bredvold \& Skålèn, 2016; Ateljevic \& Li, 2009). Their narratives disclose an identity constructed in terms of innovation and disruption in opposition to the literature presenting small tourism firms as more interested in perpetuating lifestyle choices (Shaw \& Williams, 2004). Their success is narrated as the capacity to evolve towards new markets and opportunities and to put in place adaptive changes. This model of entrepreneurship reflects a society where different subjects operate in a creative, proactive and adaptive way following their core values, beliefs and goals.

Some aspects of Participant 3's narrative (Table 5) revolves around the firm's capability to legally and efficiently deliver high quality services compared to the weaknesses of other responsible tourism firms. The owner-manager speaks predominantly in the first person plural as he focuses on the firm's team. Nevertheless, the recurrent use of impersonal and generic subjects, such as people, travellers, travel agencies, and tour operators, alongside the use of 'you' make the narrative more persuasive in terms of its ascribing meaning. On occasions, this section assumes the tone of a theoretical enunciation. He highlights the strong relationship between the high quality services his firm provides and his commitment to social projects and the prices he charges customers. Respecting the law, being efficient, getting involved in social projects and providing expensive holidays for travellers are interconnected features of the firm (lines 54 - 55); 'respecting those [laws], you fit into a context, where, it would be totally illogical not to give a high-quality service' (line 45), 'because I have to charge it properly' (line 46).

< Insert Table 5 about here - Caption: Table 5 - Participant 3 - Source: 'Tables' file> 
Participant 3 further argues that high quality services means high costs and the responsible tourism sector should accept this; 'we are our own worst enemy' (line 59), and 'the world of responsible tourism plays downward' (line 60). The narrator believes that being able to compete in the market system with big tour operators is crucial; 'we are forced to fight with teeth and crawls' (line 64), 'that ultimately lead us to be, ultimately, from an external point of view, exactly, like a traditional tour operator' (line 65). There are several references to prices and costs and frequent comparisons with big firms (lines 52, 53, 58 and 65), which frames the narrative with economic and pragmatic reasoning; 'tourism is an economic activity' (line 72). Competing with traditional tour operators and winning contracts to provide services for the big tour operators is the key to success; 'in my opinion, this is the key to success in the world of responsible tourism' (line 68). This is why the firm appears to be particularly efficient at overcoming the limits of responsible tourism.

Participant 4 (Table 6) describes himself as a self-made entrepreneur with narcissistic features (line 148). This opening represents a general introduction and what might be described as 'literary incipit', as he uses the third person singular. The narrator describes at length the wider contexts of each theme that he introduces. Stanza 41 outlines his personal satisfaction and fulfilment whilst at the same time, he claims: 'I am somehow, well, a slave to my own successes' (line 149). The words 'slave' and 'narcissistic' are used to describe the narrator's inability to recognise when a project - his 'creature' - can no longer survive (line 151). Nonetheless, the firm guarantees both his personal and economic fulfilment (line 153).

< Insert Table 6 about here - Caption: Table 6 - Participant 4 - Source: 'Tables' file>

The focus of Participant 4's narrative moves from the narrator's astonishment at their economic achievements, to the money they have invested in developing countries, generating local economic development (Stanza 42 - 44, in Table 7). The fact that he only becomes aware of this when preparing data for public communications is significant because it implies that he does not often think about this aspect. Moreover, he claims that this amount is different from the 'development fund' generated through the shares project (line 155). His personal astonishment: ' $F^{* *} k$ ! We have made more than three million euros' (line 160) - reported as direct speech - is compelling and emphatic. The narrator highlights that this sum is the result of a long and enduring process; 'drops in the sea' (lines 161 - 162). In the end, it brings 'great satisfaction' (line 163). 
< Insert Table 7 about here - Caption: Table 7 - Participant 4 - Source: 'Tables' file>

The empathic 'free speech' narrative type

The empathic 'free speech' narrative type gives meaning to the emotional attachment that participants show for their firms, customers and local partners through a frank, open and critical self-introduction. Here, participants largely understand their emotional and empathic attachment to customers and partners in terms of a search for trust, legality and transparency. Participants see themselves as truth-tellers and free speakers concerning the challenges and constraints they experienced due to global economic inequalities, weaknesses and lack of transparency. The empathic 'free speech' narrative type resonates with the classical Greek notion of parrhesia, which literally means 'all-telling' and - by extension - 'to speak freely'. This notion pictures the obligation to speak the truth for the sake of the common good, even at personal risk (Sluiter \& Rosen, 2004; Lardinois 2011); hence, the notion of parrhesia and the role of the 'truth-teller' - the parrhesiast - implies an asymmetry of political power, whereby the parrhesiast is usually inferior to his/her recipient. Participants' parrhesia consists of the freedom to criticise others' moral apathy and ambiguities openly, juxtaposing this to their own moral rectitude and frankness (Colclough, 1999; Novak, 2006; Sharpe, 2007). The parrhesiastics attribute to themselves higher moral qualities and a deeper understanding of reality than others. These self-perceived moral qualities apparently permit them not only to know and tell the truth, but also to disclose to others what is "the right thing to do".

Participant 5 (Table 8), for example, poses the question of what makes tourism responsible as a sort of personal outburst; 'so, I don't know whether I can speak freely now or you have questions' (line 63), 'I mean maybe, stop me, if you need explanations' (line 64), 'then I came to my own, personal, let's say, classification, I mean, decision' (line 67). Of central importance is choosing a partner that shares your vision and values (lines $69-70$ ). The narrator uses a vivid image to describe this point: 'I mean, the stronger this commonality of ideals is, the more legs the thing, the relationship, has' (line 70). The image of a relationship with 'legs', implying it is alive and dynamic. Thus, having legs means being able to proceed, to move on, and to concretely reach objectives (line 71).

< Insert Table 8 about here - Caption: Table 8 - Participant 5 - Source: 'Tables' file> 
Participant 6 (Table 9) describes his firm as quite 'grown-up' (line 11), 'a big boy' (line 12), and 'almost an adult already' (line 13). Stanza 03 personifies the firm by drawing a meaningful parallel between the firm and an adolescent maturing into adulthood. The repetition of the verb 'was born' (lines 14 and 15) reinforces this parallel as it describes the juvenile idea conceived by two young boys who were enthusiastic about nature and willing to create something new (line 16); 'at that time, the two founders were really young' (line 20). She emphasises the firm's naïve, inspired, and unprofessional beginning; 'it was born maybe even somehow by chance' (line 15). Indeed, it all began with a rudimentary idea based on the boys' wishes and desires. The repetition of the word 'idea' (lines 14, 16, 19, 22 ) is important as it emphasises their feelings of desire (lines 14, 16 and 22) and happenstance (lines 15 and 18).

< Insert Table 9 about here - Caption: Table 9 - Participant 6 - Source: ‘Tables' file>

\section{Conclusion}

This paper has argued that narrative research offers the prospect of a more creative approach to the study of tourism. It rests on the premise that, as Garud et al (2014: 1182) note, 'narratives are performative: they trigger action as ... (actors) ... try actualizing the very arrangements they have proposed in order to generate meaning around their ventures'. The resulting insights may challenge and potentially disrupt knowledge generated through more widely used methodological approaches.

A study of small socially and environmentally conscious tourism businesses was used to demonstrate the application of the linguistic narrative approach and, in turn, to show how novel findings might emerge as a result. In this case, the findings challenge ideas that small tourism firms that are not commercially oriented and not interested in growth (Ateljevic \& Doorne, 2000; Gray, 2002), do not have an entrepreneurial attitude (Shaw \& Williams, 2004), and routinely face managerial limitations and constraints (Thomas et al, 2011). The paper argues that the methodological approaches routinely used in this aspect of tourism research have disclosed a partial understanding of the complexity of values that inform the decision-making of small socially and environmentally oriented tourism firms. The potential of exploring narratives offers an additional approach to interpreting the meanings ascribed by actors to their actions.

Most previous attempts to understand the values that inform the choices made by ownermanagers of small tourism firms have used conventional methods such as questionnaires 
and interviews of various types, comparative analysis of secondary data or mixed methods (e.g. Ateljevic and Doorne, 2004; Sampaio et al. 2011; Font et al., 2016). While valuable, by paying insufficient attention to the individual socio-political dimension of the firms' ownerfounders/managers, together with a well-rounded understanding of their driving values, identities, and sense of self, lead to less nuanced understanding than is now possible.

The application of a narrative analysis to the study of small tourism firms allows us to look beyond polar dichotomies since one participant's narrative can share elements of another. A creative and rigorous narrative approach allows us to see how small values-based tourism firms' owners-managers construct their identity around proactive critiques of contemporary society, the global economy and mainstream tourism. Owner-managers' first person accounts predominantly focus on values and beliefs rooted both in alternative paradigms of development and growth and in postmodern conceptualisations, such as citizenship over consumerism (Elkington, 1998; Klein, 2000), de-growth (Latouche, 2004), ethical consumerism (Moore, 2004; Nicholls \& Opal, 2005), not-conventional entrepreneurship (Bredvold \& Skålèn, 2016;; Shaw \& Williams, 2004, liquid self-affirmation (Bauman, 2000), conviviality (Illich, 1971), and parrhesiastic frankness (Lardinois, 2011; Novak, 2006; Sharpe, 2007; Sluiter \& Rosen, 2004). By adopting a narrative approach, the apparently disconnected elements of each first person account are seen as part of a whole meaningful understanding.

The particular novelty of the research reported in this paper lies in its moving beyond what the participants' report through stories and narratives to analysing and interpreting the subtle and unconscious understanding expressed via linguistic choices, non-verbal utterances, and the temporal and causal sequences of their story-telling. This allows for the 'unpacking' and interpreting of narrative data though a tailor-made narrative analysis (Riessman, 1993). By so doing, the study illustrates a new way of 'knowing' that has almost been disregarded within tourism studies thus far.

The reported empirical insights are deliberately limited; our goal was to use data for illustrative purposes as part of making a contribution to methodological debates in tourism rather than to research on tourism entrepreneurship. Some critics may highlight the limitations of narrative research in terms, perhaps, of positivist notions generalisability. This is not a criticism we would accept, arguing instead that the data and analysis reveal hitherto hidden insights that are generalisable to the theoretic (Yin, 2018).

\section{References}


Andrews, M, Squire, C. \& Tomboukou, M. (Eds.) (2013). Doing narrative research, $2^{\text {nd }}$ Edition. London: sage.

Ateljevic, I. \& Doorne, S. (2000) 'Staying Within the Fence': Lifestyle Entrepreneurship in Tourism. Journal of Sustainable Tourism, 8 (5), pp.378-392.

Ateljevic, J. \& Doorne, S. (2004) Diseconomies of scale: A study of development constraints in small tourism firms in central New Zealand. Tourism and Hospitality Research, 5 (1), p.5.

Ateljevic, J. \& Li, L. (2009) Tourism Entrepreneurship - Concepts and Issues. in Ateljevic J. (ed) Tourism and Entrepreneurship: International Perspectives, p.9.

Bauman, Z. (2000) Liquid Modernity. Cambridge, UK: Malden, MA, Polity Press.

Boje, D.M \& Durant, R. (2013) Free Stories! Tamara Journal for Critical Organization Inquiry, 5 (3).

Bredvold, R. \& Skålén, P. (2016) Lifestyle entrepreneurs and their identity construction: A study of the tourism industry. Tourism Management, 56, pp.96-105.

Buchanan, D. (2013) Getting the story straight: Illusions and delusions in the organizational change process. Tamara Journal for Critical Organization Inquiry, 2 (4).

Chase, S.E. (2005) Narrative Inquiry: Multiple Lenses, Approaches, Voices. In: N. K. Denzin $\&$ Y. S. Lincoln eds. The Sage handbook of qualitative research $3^{\text {rd }}$ ed. Thousand Oaks, CA, Sage Publications Ltd, pp.651-679.

Colclough, D. (1999) Parrhesia: The Rhetoric of Free Speech in Early Modern England. Rhetorica: A Journal of the History of Rhetoric, 17 (2), pp.177-212.

Cunliffe, A.L., Luhman, J.T. \& Boje, D.M. (2004) Narrative Temporality: Implications for Organizational Research. Organization Studies, 25 (2), pp.261-286.

Davies, B. \& Harré, R. (1990) Positioning: The discursive production of selves. Journal for the Theory of Social Behaviour, 20 (1), pp.43-63 s[sep?

Denzin, N.K. \& Lincoln, Y.S. (2005) The SAGE Handbook of Qualitative Research. $3^{\text {rd }}$ ed. Thousand Oaks, CA: Sage Publications.

Elkington, J. (1998) Cannibals with Forks: The Triple Bottom Line of 21st Century Business. Gabriola Island, Stony Creek: New Society Publishers. 
Font, X., Garay, L. \& Jones, S. (2016) Sustainability motivations and practices in small tourism enterprises in European protected areas. Journal of Cleaner Production, 137, pp.1439-1448.

Garud, R., Gehman, J. \& Giuliani, A P (2014). Contextualizing entrepreneurial innovation: A narrative perspective. Research Policy, 43: 1177 - 1188.

Gee, J.P. (1991) A linguistic approach to narrative. Journal of Narrative and Life history, 1 (1), pp.15-39.

Gee, J.P. (1989) Two styles of narrative construction and their linguistic and educational implications. Discourse Processes, 12 (3), pp.287-307.

Gee, J.P. (1986) Units in the production of narrative discourse. Discourse processes, 9 (4), pp.391-422.

Gray, C. (2002) Entrepreneurship, resistance to change and growth in small firms. Journal of Small Business and Enterprise Development, 9 (1), pp.61-72.

Illich, I., (1971) Deschooling society. New York: Harper \& Row.

Klein, N. (2000) No logo: Taking aim at the brand name bullies. Toronto: Knopf Canada.

Lardinois, A. (2011) The Parrhesia of young female choruses in ancient Greece. in Athenassaki, L. and Bowie, E. (eds) Archaic and classical choral song: Performance politics and dissemination, pp.161-172.

Latouche, S. (2004) Degrowth economics. Le Monde Diplomatique, 11.

Moore, G. (2004) The Fair Trade movement: parameters, issues and future research. Journal of Business Ethics, 53 (1), pp.73-86.

Nicholls, A. \& Opal, C. (2005) Fair trade: market-driven ethical consumption. London: Sage Publications.

Novak, D.R. (2006) Engaging Parrhesia in a Democracy: Malcolm X as a Truth-teller. Southern Communication Journal, 71 (1), pp.25-43.

Reissner, S. \& Pagan, V. (2013). Storytelling in management practice. Dynamics and implications. London: Routledge.

Rhodes, C. \& Brown, A.D. (2005) Narrative, organizations and research. International Journal of Management Reviews, 7 (3), pp.167-188. 
Riessman, C.K. (1990) Strategic uses of narrative in the presentation of self and illness: A research note. Social Science \& Medicine, 30 (11), pp.1195-1200.

Riessman, C.K. (1993) Narrative analysis. London: Sage Publications.

Riessman, C.K. \& Quinney, L. (2005) Narrative in Social Work A Critical Review. Qualitative Social Work, 4 (4), pp.391-412.

Sampaio, A.R., Thomas, R. \& Font, X. (2011) Small business management and environmental engagement. Journal of Sustainable Tourism, pp.1-15.

Sharpe, M. (2007) A question of two truths? Remarks on parrhesia and the 'politicalphilosophical 'difference. Parrhesia, 2, pp.89-108.

Shaw, G. \& Williams, A.M. (2004) From Lifestyle Consumption to Lifestyle Production: Changing Patterns of Tourism Entrepreneurship in Thomas, R. (ed.) Small firms in tourism: International perspectives (Advances in Tourism Research) Routledge. pp99-111.

Sluiter, I. \& Rosen, R.M. (2004) Free speech in classical antiquity:[Penn-Leiden Colloquium on Ancient Values, June 2002 at the University of Pennsylvania]. Brill.

Smith, B. \& Sparkes, A.C. (2008) Narrative and its potential contribution to disability studies. Disability \& Society, 23 (1), pp.17-28.

Smith, C.P. (2000) Content analysis and narrative analysis. In. Reis, H. (ed.) Handbook of research methods in social and personality psychology, Cambridge University Press, pp.313-335.

Thomas, R., Shaw, G. \& Page, S.J. (2011) Understanding small firms in tourism: a perspective on research trends and challenges. Tourism Management, 32 (5), pp. 96.3-976

Tsoukas, H. \& Hatch, M.J. (2001) Complex Thinking, Complex Practice: The Case for a Narrative Approach to Organizational Complexity. Human Relations, 54 (8), pp.979-1013.

Walmsley, A. (2019). Entrepreneurship in tourism. London: Routledge.

Wilkins, A.L. \& Thompson, M.P. (1991) On getting the story crooked (and straight). Journal of Organizational Change Management, 4 (3), pp.18-26.

Yin, R. K. (2018) Case Study Research and Applications: Design and Methods. $6^{\text {th }}$ ed. Thousand Oaks, CA: Sage Publications. 